\title{
Interictal psychosis: a case report and review
}

\section{Psicose interictal: relato de caso e revisão de literatura}

Dear Editor,

Epilepsy is the most prevalent of the potentially ominous neurological disorders, affecting over 50 million individuals worldwide, $80 \%$ of them living in developing countries. ${ }^{1}$ Accordingly, epilepsy represents a significant public health issue. ${ }^{2}$ Epilepsy and mental disorders are comorbid, and from 19 to $52 \%$ of adults with epilepsy have psychiatric disorders. ${ }^{3}$ Psychiatric disorders can be identified in $25-50 \%$ of patients with epilepsy, with higher prevalence among patients with poorly controlled seizures. These disturbances include depression, anxiety, psychotic disorders, cognitive, and personality changes occurring in the interictal or ictal/postictal states. ${ }^{4}$

Herein we report the case of a patient with epilepsy since the age of 10 years. At the age of 34, he claimed he suddenly discovered the "mystery of the words", as well as "the art of writing, the gift of demagogy, nationalism, politics and romance". He developed

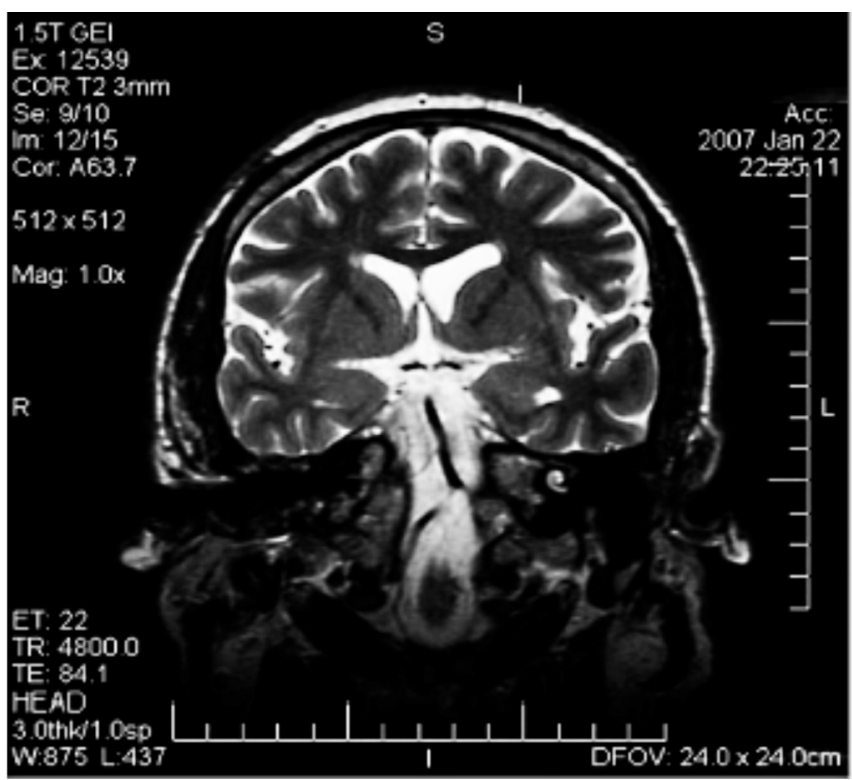

Figure 1 - Magnetic resonance imaging showed mild and bilateral temporal lobe atrophy, signal attenuation on the pallidus and right hippocampus, dilated choroid fissure and a diminished fornix, suggesting right mesial temporal lobe sclerosis. 
paranoid symptoms. At this time he reported that his "ego" started turning against him. He could hear his own voice, cursing him continuously and telling him to do various things such as eating someone's excrements. He said he was sure that this was his ego since he had studied psychoanalysis extensively and had "selfknowledge".

He remained without treatment until he was 41, when he initiated psychiatric treatment, being prescribed Haloperidol $10 \mathrm{mg} / \mathrm{day}$ and Biperiden $4 \mathrm{mg} / \mathrm{day}$. He felt calmer at the beginning, but eventually became progressively more disturbed, feeling that not only his ego, but also his soul, superego, id and personality progressively turned against him.

In December 2006, aged 46, he presented to the Mood Disorders Unit (GRUDA), School of Medicine of the Universidade de São Paulo and was admitted for inpatient investigation and treatment. As clinical antecedents he had a previous exploratory laparotomy, blood hypertension, diabetes, and obesity. The psychiatric exam revealed an apathetic patient, not receptive to contact. He had blunted affect, even when stimulated with humor. He responded with brief answers and recurrently talked about being persecuted, claiming that his ego took away the "emotions" from his bowels, making him evacuate. He also complained of weakness on his legs, and justified it as the consequence of his ego and superego making him unable to walk.

Subsidiary tests (including serological tests for HIV, syphilis and hepatitis) were all normal. Electroencephalogram showed epileptic activity with continuous discharges on the temporal regions, bilaterally. Magnetic resonance suggested right mesial temporal lobe sclerosis (Figure 1). Neuropsychological evaluation revealed impairments in areas related to attention, language, visual-spatial organization, planning, memory and executive functions.

Patient was using Carbamazepine 600mg tid, Phenobarbital $200 \mathrm{mg}$ tid and Clonazepam $2 \mathrm{mg}$ tid. He was also using Haloperidol, Biperiden and Promethazine, all of them were suspended. Carbamazepine was increased to $800 \mathrm{mg}$ tid and Ziprasidone was started at $80 \mathrm{mg}$ and titrated to $240 \mathrm{mg}$ tid over 3 weeks. Carbamazepine was switched to Oxcarbazepine $1200 \mathrm{mg}$ tid, for a better drug interaction profile.

He maintained tonic-clonic seizures, once every 2 months. During treatment he progressively developed better contact, greater affective tonus and variability as well as a reactive mood. Although full remission of the psychotic disorder and of epilepsy were not achieved, treatment significantly improved the functional impact of these disorders.

\section{Ricardo Alberto Moreno, Carlos Henrique Rodrigues dos Santos}

Mood Disorders Unit (GRUDA). Department and Institute of Psychiatry, Clinical Hospital, School of Medicine, Universidade de São Paulo (USP), São Paulo, SP, Brazil

Renato Luiz Marchetti

Epilepsy Unit (PROJEPSI), Department and Institute of Psychiatry, School of Medicine, Universidade de São Paulo (USP), São Paulo, SP, Brazil

\section{Disclosures}

\begin{tabular}{|c|c|c|c|c|c|c|c|}
\hline $\begin{array}{l}\text { Writing group } \\
\text { member }\end{array}$ & Employment & $\begin{array}{l}\text { Research } \\
\text { grant }^{1}\end{array}$ & $\begin{array}{l}\text { Other research grant or } \\
\text { medical continuous } \\
\text { education }\end{array}$ & $\begin{array}{l}\text { Speaker's } \\
\text { honoraria }\end{array}$ & $\begin{array}{c}\text { Ownership } \\
\text { interest }\end{array}$ & $\begin{array}{l}\text { Consultant/ } \\
\text { Advisory } \\
\text { board }\end{array}$ & Other $^{3}$ \\
\hline $\begin{array}{l}\text { Ricardo Alberto } \\
\text { Moreno }\end{array}$ & $\begin{array}{l}\text { USP } \\
\text { Private } \\
\text { practice }\end{array}$ & FAPESP* & $\begin{array}{c}\text { BMS }^{* *} \\
\text { AstraZeneca** }^{* *} \\
\text { Servier** }\end{array}$ & - & - & $\begin{array}{c}\text { CEIP } \\
\text { ABTB } \\
\text { ABP } \\
\text { A. Lopes } \\
\text { Munis } \\
\text { Advogados } \\
\text { Mattos Muriel } \\
\text { Kestener } \\
\text { Advogados }\end{array}$ & $\begin{array}{l}\text { Segmento } \\
\text { Farma } \\
\text { Editoras } \\
\text { Artmed } \\
\text { Editora } \\
\text { SA }\end{array}$ \\
\hline $\begin{array}{l}\text { Carlos Henrique } \\
\text { Rodrigues dos } \\
\text { Santos }\end{array}$ & USP & - & - & - & - & - & - \\
\hline $\begin{array}{l}\text { Renato Luiz } \\
\text { Marchetti }\end{array}$ & USP & - & - & - & - & - & - \\
\hline \multicolumn{8}{|c|}{$\begin{array}{l}{ }^{*} \text { Modest } \\
* * \text { Significant } \\
\text { *** Significant: Amounts given to the author's institution or to a colleague for research in which the author has participation, not directly to the } \\
\text { author. } \\
\text { Note: USP = Universidade de São Paulo; FAPESP = Fundação de Amparo à Pesquisa do Estado de São Paulo; CEIP = Centro de Estudos do } \\
\text { Instituto de Psiquiatria; ABTB = Associação Brasileira de Transtorno Bipolar; ABP = Associação Brasileira de Psiquiatria. } \\
\text { For more information, see Instructions for authors. }\end{array}$} \\
\hline
\end{tabular}

References

1. Scott RA, Lhatoo SD, Sander JW, The treatment of epilepsy in developing countries: where do we go from here? Bull World Health Organ. 2001;79(4):344-51.

2. de Boer HM, Mula M, Sander JW. The global burden and stigma of epilepsy. Epilepsy Behav. 2008;12(4):540-6.
3. Swinkels WA, Kuyk J, van Dyck R, Spinhoven P. Psychiatric comorbidity in epilepsy. Epilepsy Behav. 2005;7(1):37-50.

4. LaFrance WC Jr, Kanner AM, Hermann B, Psychiatric comorbidities in epilepsy. Int Rev Neurobiol. 2008;83:347-83. 